\title{
deus-dará: o Rio de Janeiro como espaço de (des)encontro durante séculos
}

\author{
Helena Gonçalo Ferreira*
}

deus-dará é um romance de Alexandra Lucas Coelho, descrito ao longo de sete dias, em diferentes anos, revelando uma clara inspiração no Génesis, que nos apresenta sete personagens como o seu subtítulo destaca: "sete dias na vida de São Sebastião do Rio de Janeiro ou o Apocalipse segundo Lucas, Judite, Zaca, Tristão, Inês, Gabriel \& Noé”. Tristão é um português que já vive no Rio e o apresenta a uma portuguesa - Inês - que acaba de chegar e nunca tinha estado ali. Os dois apresentam a cidade aos leitores. Os restantes personagens são brasileiros: Gabriel é crioulo e usa uma pala num olho, Zaca através das suas fotografias dá-nos a conhecer uma grande parte da história do Brasil com a mesma intensidade com que nos mostra a sua homossexualidade, Lucas é afro-índio e ficou mudo durante anos, após ter descoberto a mãe morta dependurada numa árvore. Judite e Noé possuem a capacidade de nos prender à leitura pelas suas vidas eróticas tão distintas.

Através destas personagens e com o Rio de Janeiro presente, o narrador híbrido que tanto escreve em português de Portugal como em português do Brasil, conduz os leitores ao longo de cinco séculos de história, bem como às conjunturas sociais, religiosas e culturais de Portugal e do Brasil durante o período da colonização e pós-colonização. Ao longo deste relato fica demonstrado que os movimentos anticoloniais apenas conseguiram a independência dos territórios, porque eternizaram a colonialidade do poder e do saber geradas no colonialismo, fazendo perpetuar a condição subalterna das sociedades dos países colonizados. Devido a esta colonialidade, as elites estatais e intelectuais do Brasil decidiram construir o seu Estado à semelhança do Ocidente, negando-lhe o direito a uma identidade própria e à afirmação das minorias, conduzindo-o para uma crise política interminável. Deste modo, as identidades pós-coloniais que têm a sua origem no conceito de "raça", e que foram organizadas pelo Ocidente em humanas e sub-humanas misturam-se com as identidades que se revelaram devido ao conceito binário que organiza o mundo em normais e desviados, ou seja, identidades queer.

Estamos assim perante uma obra de fronteiras, de espaços híbridos de produção de identidades transversais (PrECIADo, 2011), que foge ao normativo, à homogeneização cultural, à categorização e à heteronormatividade e que se ocupa dos

Doutoranda do Programa em Estudos Culturais na Universidade de Aveiro, Aveiro, Portugal. Email: helenacarlag@gmail.com. 
portugueses colonizadores que chegaram ao Brasil e dos povos que lá encontraram, dos escravos que foram retirados das suas terras e explorados no Brasil, da sociedade que se organizou em consequência da colonização, constituída pela burguesia que domina o país e pelas minorias oprimidas, na sua grande maioria negras, "mestiças" e indígenas.

\section{Vida: vidas queer}

Questionada sobre a palavra que faz a ligação entre todos os seus livros, Alexandra Lucas Coelho responde: "vida" (CoELHo, s.d., s.p.). Vidas queer é a grande essência deste livro, entendendo queer como muito mais que os sujeitos das sexualidades ditas "desviantes". Para Sam Bourcier “queer não é apenas uma questão de gênero, é sobre política sexual, racismo, biopolítica, análise e luta contra o neoliberalismo" (Bourcier, 2015, s.p.). Além disso, prevê uma "agenda múltipla de associação para a transformação social e justiça econômica. Feminista, antirracista, anti-imperialista e anticolonialista, que defende a proliferação de gêneros além da ficção de diferença sexual" (BoucıER, 2015, s.p.). Butler vai ao encontro deste mesmo raciocínio quando defende que o queer deverá servir para unir as minorias através da diferença, ou seja, pertencer ao movimento queer "passa por combater políticas favoráveis à discriminação, citando sobretudo as minorias sexuais, raciais, religiosas e as mulheres" (BUTLER, 2017, s.p.).

Passemos, então, a conhecer estas vidas queer presentes numa sociedade hierarquizada, colonizada, homofóbica e racializada: Lucas é um gigante de 1,97m e $90 \mathrm{Kg}$, cuja altura vem "de muitas gerações atrás, lá em África, [...] filho e neto de mestiços do Pará"(CoElho, 2016, p. 84). É um "índio arraçado de negro e de branco"(Coelho, 2016, p. 85) que nasceu no final de 1991. O seu pai morreu quando ele tinha 5 anos, "no massacre Eldorado dos Carajás, quando a Polícia Militar do Pará atacou a manifestação dos sem-terra que ele ajudara a organizar" (Coelho, 2016, p.86). Quando tinha 19 anos, mudou-se com a mãe da Amazónia para o Rio de Janeiro e "bateu de frente com o facto de não ser branco no Brasil"(Coelho, 2016, p. 87), já que "um bróder como ele disparava alarme, do Fashion Mall ao Shopping Leblon. Qualquer rolêzinho no meio dos ricos podia acabar na delegacia" (CoELHo, 2016, p.87).

Dividiam aluguel com uns parentes no sopé da rocinha. A mãe virou assistente de uma artista budista e Lucas entrou em História na Universidade Estadual do Rio de Janeiro sem precisar "recorrer a cota de aluno de escola pública ou não branco"(Coelho, 2016, p.86). Numas férias de Natal de 2011, Lucas e a mãe foram visitar os avós à Amazónia e aconteceu uma grande tragédia. Na noite de réveillon, a mãe de Lucas foi violada e estrangulada, no meio do mato, por um homem que tinha sido seu namorado quando era muito jovem. Lucas encontrou o corpo da mãe pendurado numa seringueira e quase foi morto pelo assassino que lhe puxou o cabelo e o tentou sufocar. Para se defender, Lucas empurrou-o contra uma árvore e furou-lhe a carótida. De regresso ao Rio, Lucas deixou de falar e rapou o cabelo. 
Também deixou de estudar e arranjou trabalho, é ascensorista: "um homem dentro de uma caixa, seis horas por dia”(Coelho, 2016, p. 92).

Lucas não se queixa, porque "não é da facção herdeiros-de-esquerda, sabe como a fome come por dentro" (Coelho, 2016, p. 227). Quando não está a trabalhar, está a fazer murais ou a navegar pela cidade de skate. Conheceu Noé (um nome bíblico, predominantemente masculino, que significa paz, alívio e consolo) numa manifestação contra o despejo da Aldeia Maracanã, ordenado pelo governador Sérgio Cabral quando os manifestantes foram atacados pela Polícia Militar. Noé estava grávida, foi empurrada, caiu e foi socorrida por Lucas que a levou para o hospital. Apesar disso, abortou. Noé é "mignonzinha, carapinha black power, [...] filha de mãe negra, pai vai saber” (CoELHo, 2016, p. 36). É universitária, bolsista de ciência política da PUC, universidade católica particular, "onde os não-bolsistas pagam dois mil reais por mês". Trabalha como babá. Ativista e feminista, Noé debate-se por várias causas, como a legalização do aborto que "era só uma das razões para fazer uma revolução nesse país que vive ligado em sexo mas persegue mulher que aborta" (CoElHo, 2016, p.109).

Entretanto, envolve-se com Lucas e os dois apaixonam-se. Noé engravida, os dois decidem ficar juntos. Lucas volta a estudar e Noé resolve entrar na política. Noé, tal como outras personagens aqui descritas, é uma identidade de fronteira, das margens: mestiça, ativista, feminista, a representar um lugar de periferia e de subalternidade (ANZALDÚA, 1987). O seu lugar de fala a lembrar sempre ao mundo, o racismo, as diferenças de género, a colonização. O seu discurso transgressor a provar que o subalterno, afinal, fala, lutando contra a dimensão de poder de uma hierarquia violenta que dita quem pode ou não ter voz. Muito embora, esta voz seja a do marginalizado, a desviante, a "anormal", porque a que continua centro, a norma, é a do homem, branco, ocidental, heterossexual de classe alta. Essa é a voz do conhecimento, dos factos, do imparcial, do racional, do objectivo, universal e científico. O subalterno terá apenas a voz das experiências, das opiniões, do parcial, emocional, subjetivo, muito específico e nada científico (KILOMBA, 2010). Ou seja, o subalterno fala, o Ocidente é que não ouve porque o que é diferente da sua voz, não lhe interessa, porque o considera inferior.

Judite, irmã de Zaca e Karim (que se encontra na Síria), tem 1,8om e é descrita pelo narrador com paixão, para quem ela "pode tudo" (CoELHo, 2016, p. 19). O narrador está perdido de amores por ela e escreve-o assim, a cada página que a relata. Caucasiana, de cabelo cor de cobre, é irmã de Zaca e está perdidamente apaixonada por Gabriel. Ex-aluna de colégio de freiras, já foi modelo e está prestes a ser sócia do maior escritório de advogados do Rio. Judite é "um arraso, muda o ar em volta dela" (Coelho, 2016, p. 53) e "gosta de tudo o que mexa, mas sobretudo de homens" (Coelho, 2016, p.53). Bebe muito e parece "nascida para trepar" (CoElho, 2016, p.108). Mais uma vez, o sistema patriarcal a invocar que não é comum que uma mulher goste muito de sexo. 
A norma dita que as mulheres não gostam de sexo, que o sexo proporciona pouco prazer e serve apenas para as deixar grávidas. "O sistema quer-nos recatadas, discretas, tranquilas" (ToRREs, 2015, p. 82), essa é a forma de mostrar que a sexualidade nas mulheres existe apenas para servir o homem, a espécie e a produção de capital. O patriarcado sempre utilizou múltiplos mecanismos para impedir as mulheres de "nascerem para trepar". Como Diana Torres afirma "perdemos séculos de prazer, orgasmos, desejo e trazemos isso na nossa memória celular, das nossas mães, avós, bisavós e assim, por gerações e gerações" (TorREs, 2015, p. 82). Judite é apenas uma das mulheres que tem plena consciência que perderam imenso tempo a seguir o sistema normativo patriarcal e se encontra disposta a recuperá-lo.

Gabriel, é o "anjo moreno" (CoElho, 2016, p. 17) de Judite. Chamam-lhe pirata crioulo, porque tem uma pala no olho esquerdo que "se foi num estilhaço, briga de facções cariocas, nem notícia”(Coelho, 2016, p. 37), quando era garoto. Para aqueles que acham que não existem piratas de pala no olho no século XXI, convém dizer que "a probabilidade de um estilhaço furar o olho de um garoto na periferia do Rio é diária [...] e que essa bala tanto pode vir de um traficante como da polícia ou do exército" (CoElho, 2016, p. 200). Gabriel é sociólogo do Instituto de Filosofia e Ciências Sociais da Universidade Federal do Rio de Janeiro, bastião da universidade pública. É um mulherengo machista com um filho de 14 anos. Melhor amigo de Noé, que conhece do Complexo do Alemão. Trata as mulheres como se fossem descartáveis e por isso ia terminar com Judite, mas ela deixa-o a meio dessa tarefa, "porque nenhum homem lhe dissera essa frase, e aquele não seria o primeiro"(CoElHo, 2016, p. 253). A relação acaba assim, sem que ninguém a tenha terminado. Judite casa com Rosso ao sexto dia, fica viúva ao sétimo e Gabriel envolve-se com mais umas quantas, incluindo Império, filiada no Partido Socialismo e Liberdade, mas que acredita que todo o sistema tem de ser mudado "a partir da rua" (CoELho, 2016, p. 339).

Tristão é um católico português que vive no Rio e que foi para lá para fazer um doutoramento em antropologia, que acaba por interromper. Vive da fotografia e é "tudo o que a carioca não sonha: sem músculo a perder cabelo antes dos 30" (Coelho, 2016, p. 47). Está enamorado de Alma, também antropóloga que estuda pinturas corporais fora do Rio de Janeiro e por isso estão poucas vezes juntos. Tal como já se referiu, é Tristão que apresenta a cidade aos leitores ao mesmo tempo que a apresenta a Inês, também portuguesa e que chega ao Rio na manhã do dia 19 de Dezembro de 2012, numa época em que muitos portugueses voaram para o Brasil (e outros destinos) porque foram incentivados pelo governo de Lisboa a emigrar. Inês parte com o objectivo de fazer uma tese de doutoramento sobre os árabes. É lésbica ou bissexual se contabilizarmos que se envolveu com Tristão, única relação heterossexual que teve. Sofre por amor, porque continua a querer a ex-companheira que "já não a quer" e se encontra em Beirute. Como bem define Alexandra Lucas Coelho, retirando-lhe o cariz heterossexual: "é a habitual 
quadrilha de que Drummond fez um poema, um ama o outro, que ama a outra que ama o outro que não ama ninguém" (CoELHo, 2016, p. 283).

Enfim, Zaca (Zacarias Souza Farah): "bíceps al dente; boca árabe, proeminente; caracóis ainda no carrapito, que lhe fica bem porque tudo lhe fica bem" (CoElHo, 2016, p. 34). Pertence, tal como a irmã, à elite carioca. Fez a biografia do maior sambista brasileiro: Leão do Morro e encontra-se a escrever um romance há imenso tempo. Ama o Cosme Velho e tem alguns preconceitos em relação à Síria: "imagina-o-fanatismo-a-opressão-a-misoginia"(CoELHo, 2016, p. 50). No início da obra "imagina-se feminista, amante de mulheres" (Coelho, 2016, p. 50), mas mais adiante ao avistar "um gato de bermuda" assume que "nunca transou com homem", mas que "pensa nisso" e não sabe se "pensa nisso porque quer escrever ou se quer escrever porque pensa nisso"(CoklHo, 2016, p. 188). Até que numa bela noite, depois de uma festa, Zaca inicia um relacionamento com Orfeu que ainda não fez 18 anos, mas que iniciou a sua vida sexual aos 12. Já no final do livro Zaca oferece um jantar em sua casa, para que todos possam conhecer Orfeu. Finalmente "sai do armário" e sente que "não estar apaixonado é bom, mas é uma merda; estar apaixonado é uma merda, mas é bom. [...] E, talvez porque apesar de tudo o que está uma merda, nunca esteve tão feliz" (CoElHo, 2016, p. 521).

Esta "saída do armário" parece perfeitamente pacífica, até porque Zaca encontra-se numa posição privilegiada. No entanto, assumir perante os outros uma orientação sexual não normativa é sempre algo violento, uma vez que a homofobia como sistema opera através do silenciamento e da invisibilidade. A realidade formatizada não está concebida para receber o homossexual que até àquele momento era alguém que vivia dentro das normas. Como Sedgwick teorizou, mesmo entre os gays mais assumidos, há muito poucos que não estejam no armário para alguém que, de alguma forma, é importante para ele. Até porque, as pessoas encontram sempre "novos muros que surgem à volta delas até quando dormitam" (SEDGWICK, 1998, p. 92). Isto é, cada novo encontro com novas pessoas ou grupos leva a abrir de novo as portas dos armários e a voltar para lá, nem que seja para reconstruir sigilos ou exposições.

Mesmo para aqueles que consideram o queer como apenas associado aos mecanismos de género/sexo, todas as personagens de deus-dará são vidas queer se considerarmos queer como "sexo-positivo" - ideologia em que todas as formas e expressões da sexualidade são vistas como forças potencialmente positivas, sempre que sejam consensuais - ou melhor, significa "sim" a encontrar a pessoa (ho$\mathrm{mem} / \mathrm{mulher}$ ) certa a qualquer momento, a estar aberta para coisas que nunca tentou, a fazer qualquer coisa, no lugar certo com a pessoa certa (OBINWANNE; BLAIR, 2017). 


\section{Ainda outras vidas}

$\mathrm{Na}$ nossa perspectiva, o livro possui mais duas personagens: o narrador e a cidade. O Rio de Janeiro se encontra presente em cada página como o ser vivo inquieto e arrebatador que já nos tinha sido apresentado por Machado de Assis, Aluísio Azevedo, Carlos Drummond de Andrade, Manuel António de Almeida e Rubem Fonseca, que fizeram questão de contar a sua história em diferentes épocas para que se pudesse entender os seus hábitos e vivências. Alexandra Lucas Coelho exibe um outro olhar sobre a cidade, por um lado porque sendo ali estrangeira/migrante, a sua visão não é a de quem sempre conheceu o lugar, mas a de quem o encontrou e se apaixonou por ele. Era como se já o tivesse conhecido e, por outro, a de colonizadora consciente, das poucas que tem memória de o ter sido.

A autora não se limita a descrever a cidade, ela transforma-a no espaço de ação e ao mesmo tempo, na testemunha principal da invasão colonial portuguesa. Como se vai lendo ao longo da obra: "Zaca tem os pés onde o mundo indígena da Guanabara conheceu o fim, e com ele um fluxo de dez mil anos, desde o interior dos sertões, constelações genéticas, mapas celestes, sonhos, falas. A parte curta da história é a dos europeus. A dos índios só não estava escrita" (CoElho, 2016, p. 24), e também na testemunha da nova colonialidade, no período de 2012 a 2014:

A nova classe média brasileira são quarenta milhões, pode ser aliciada até junto à cracolândia, no meio de jardineiros, caseiros, porteiros, motoristas, ascensoristas, manobristas, garçons, babás, cozinheiras, lavadeiras, passadeiras, faxineiras, diaristas, folguistas, todos os que servem aqueles que em linguagem da favela são os bacanas e em linguagem marxista são os burgueses da Zona Sul (Coelho, 2016, p. 27).

Esta é a cidade de encontros e desencontros, que tem uma sociedade ao deusdará, sobretudo pessoas negras e pobres que foram abandonadas pelo Estado que nunca lhes deu o básico e essencial como saúde, educação e condições de trabalho. Por isso, deus-dará, deus cuidará porque será o único a querer fazê-lo. Esta é a "cidade sensível", um fenómeno cultural que "se revela pela percepção de emoções e sentimentos dados pelo viver urbano e também pela expressão de utopias, de esperanças, de desejos e medos, individuais e coletivos, que esse habitar em proximidade propicia” (Pesavento, 2007, p.14). É uma cidade pensada, que se apresenta real aos seus habitantes e visitantes e que por sua vez, os materializa num tecido social real, concreto, palpável. Ao mesmo tempo, é uma cidade imaginada, que permite a atribuição de significados e sentido e que se transforma no "lugar", ou seja, faz parte das memórias e é portadora de um valor no tempo e no espaço que faz dos que a habitam cidadãos ou excluídos, fazendo assim parte da construção e reconstrução de identidades.

Quanto ao narrador, que conduz os leitores ao longo de cinco séculos de história, às conjunturas sociais, religiosas e culturais de Portugal e do Brasil durante 
o período da colonização e pós-colonização, para além de ter um papel político muito ativo, tem a função de incitar os leitores e as leitoras a refletirem sobre estes dois períodos da história, fazendo observações ao longo de todo o texto, destacando-se nas últimas páginas, que é onde ficamos a saber que este narrador é Nicolau Coelho, o primeiro português a ter contacto com indígenas no território que veio a chamar-se Brasil, em 1500. Conhecedor, portanto, de toda a história, é também transatlântico, uma vez que tanto escreve em português de Portugal como em português do Brasil, deixando claro que a língua não é uma cativa portuguesa, porque aqui solta-se "a pipa, a que os cariocas da idade deles já não chamam papagaio, porque o vocabulário também se soltou, ganhou nomes pelo Brasil” (COELHO, 2016, p.29).

Aliás, apesar de no livro só constar o português como língua em versão portuguesa e brasileira, consideramos que se pode adoptar aqui a ideia da mente bilingue de Pavlenko (2014), no sentido de que o processo de aprendizagem e o uso de uma nova linguagem afectam a categorização, memória, percepção e autopercepção, reformulando todos estes processos e reorganizando a estrutura da mente. Um novo vocabulário permite-nos formar novas conexões entre as palavras e os seus referentes e aprender a prestar atenção às distinções exigidas pela nova terminologia. Até porque "pipa não é só papagaio, pode ser dragão, falcão, águia, coruja, morcego, borboleta, saco de plástico, sacolinha, o que der para soltar sem custo" (CoElho, 2016, p. 30). A mão que segurava o papagaio já não é a mesma que segura a pipa, porque, de forma corajosa lutou pela sua independência, construindo e desconstruindo a sua própria identidade.

\section{Um romance transgénero transformador}

"Ceci, isto não é um cachimbo" (MAGRITTE, 1929). Nem são vários cachimbos. Ou seja, "isto" não é um romance como sempre nos disseram que os romances eram. É um romance escrito de forma inusual que não cabe numa "gaveta", e nem sequer em várias. É transgénero, como a própria autora diz que vê sempre o romance: "não como um género, mas como um transgénero, portanto, nele cabem muitas coisas" (Coelho, s.d., s.p.). Neste romance, cabem gravuras, fotos, esquemas, poemas, músicas. É camaleónico e desestabiliza convenções, porque a autora recriou novas formas e propôs novos caminhos, seguindo as normas próprias do romance que segundo Michael McKeon possui "a capacidade de mudar sem se transformar numa outra coisa” (MCKEON, 200o, p. XIV).

Acima de tudo, há que referir, que se constrói através de várias modalidades discursivas. Por um lado, narra a trama da chegada dos portugueses ao Brasil, através de factos, com veracidade, durante 500 anos, a partir do primeiro encontro entre os indígenas brasileiros e os navegadores portugueses. Por outro, faz uma narrativa imaginada da vida de sete personagens fictícias no Rio de Janeiro contemporâneo, ligando, em alguns casos, estes dois tempos. Um exemplo é Tristão, cujo nome tem origem no seu avô, que se chamava Tristão por causa do navega- 
dor Tristão da Cunha e foi "baptizado na ermida do Restelo, habituado à missa nos Jerónimos, ali onde a sorte do mundo se armou, jogando hemisférios às metades, caravelas e naus para todas as partes, bem mais partidas do que regressos, muito mais mortos do que imortais" (CoELHo, 2016, p.112).

Neste tempo atual, na "cidade maravilhosa" a autora oferece-nos ainda relatos de factos verídicos juntamente com os acontecimentos ficcionais que os personagens vivem. A fronteira entre o que é real e o que é fictício é tão ténue que todos os acontecimentos se transformam em verosímeis. Um exemplo é o trecho em que que Gabriel se torna pai, porque conhece a mulher com quem vem a casar e a ter um filho, "uma burguesa hippie do Leblon", Débora Klein, num evento que ocorreu mesmo no Rio de Janeiro, no inverno de 1992, a "maior manifestação alguma vez realizada na cidade"(CoElHo, 2016, p.119), com o intuito de lutar pelo impeachment de Collor de Mello.

Estamos perante uma metaficção historiográfica que não é nem mais nem menos que um romance que engloba história, ficção e teoria baseadas em acontecimentos e/ou personagens reais em que se reescreve o passado dentro de um novo contexto. De facto, existe nesta obra um grande trabalho de pesquisa, mas os factos não foram narrados com objectividade e neutralidade, foram interpretados, isto é, a autora sentiu-se livre para reavaliar a história do passado e de a transformar numa outra narrativa (HuTCHEON, 1991).

Como autora do pós-colonialismo, deu voz aos "outros", àqueles que não a possuíam e que foram discriminados durante séculos. Isto é "transformar o diferente, o off-centro, no veículo para o despertar da consciência estética e até mesmo política" (Hutcheon, 1991, p. 103). Bojić (2008) refere que as intenções das autoras definem sempre as direções que os textos assumem, ou seja, os textos de ficção são sempre ideológicos, apesar das autoras se esforçarem para que a dimensão política do texto passe despercebida. Não me parece ser esse o caso de Alexandra Lucas Coelho, para quem o importante é que se

fale disso, explicar o que aconteceu, porque os mortos estão vivos agora. Os mortos e os escravizados tiveram filhos, que tiveram netos, que tiveram bisnetos. São essas pessoas que estão debaixo dos pés do Brasil agora. Não se trata de substituir uma versão pela outra, mas sim de tudo ter acontecido. Eles [navegadores] foram bravíssimos, audaciosos, puseram os vários mundos a encontrar-se. Não vou contra isso mas já lhes prestámos tributo. Podemos olhar agora para os mortos e escravizados? (COELho, 2016, s.p.).

A autora rejeitou, então, a realidade ordenada apresentada até agora e esta escrita metaficcional contribuiu para um sentido mais completo de que a realidade e a história. São realidades provisórias porque não há um mundo de verdades eternas, mas uma série de construções, artifícios e estruturas impermanentes (WAUGH, 1984). Esta reflexão crítica intensifica-se no romance e alastra-se pelos 
vários campos do conhecimento. Estendendo a discussão à história, atribuindo uma voz e um rosto aos indivíduos que ficaram excluídos, como, por exemplo, à Noé que, no fundo, representa um pouco, "a mulher negra no Brasil, as estupradas que fizeram o país mestiço, as que criaram os filhos dos brancos, as forçadas a abortar e as que morreram por abortar, as que até hoje têm de dar mais tempo aos filhos dos outros para pagar as contas" (CoELHo, 2016, p. 444).

O curioso aqui é que a autora situa o seu lugar de fala no Ocidente, como branca, colonizadora, ou seja, uma privilegiada que se encontrava no lado dos vencedores e que rompe com a literatura de um narrador geo-centrado que produz conhecimentos e desqualifica outras produções de saberes condenando-as ao silêncio e/ou à subalternidade. Discutir o lugar de fala na literatura é algo complexo, até porque como Barthes (1999) referiu, o escritor é sempre alguém que fala no lugar do outro. Considera-se, por isso, o lugar de fala aqui como o lugar da resistência, como o que dá voz aos que dela foram privados e que participa do esforço para construir outra linguagem, outra gramática, outras fontes de conhecimento e outras referências que não aquelas que sempre vimos como as verdadeiras e únicas que devem ser aprendidas e ensinadas.

Estas personagens, a quem a autora deu aqui voz, são ex-cêntricas (Hutcheon, 1991) porque, no fundo, são os marginalizados que saíram do anonimato apenas porque a nossa cultura não pode mais ser vista à luz do homem branco, ocidental de classe média, heterossexual, que era a grande personagem dominante na história. Por isso os negros, as mulheres, os homossexuais, os índigenas, os pobres foram excluídos, silenciados ou exibidos segundo a visão do ocidente colonizador. Através destas personagens ex-cêntricas, a autora deu voz aos que não tinham sido ouvidos ao longo da história, aos que se encontram nas margens, mas sem tentar levá-los para o centro - a voz é a das margens - e sem uniformizar os seus discursos ou idealizá-los semelhantes aos que eram aceites pelo centro, pelo Ocidente.

\section{Colonialismo, pós-colonialismo e colonialidade}

A partir dos anos 8o surgem os estudos pós-coloniais, suscitados pela reflexão crítica de Edward Said e por outros autores vindos das periferias que se centram na procura da história daqueles que até agora eram invisíveis para o Ocidente. Este detinha o poder de narrar a história, que para todos os efeitos continha os perigos da história única, incluindo o de anulação de outras culturas (ADICHIE, 2013). A ambição de uma descolonização global e política, do saber e do poder torna premente a reescrita da história dos ex-colonizados. Alexandra Lucas Coelho demonstra, no entanto, nesta obra, que os movimentos anticoloniais conseguiram a independência dos territórios, uma vez que eternizaram a colonialidade do poder e do saber geradas no colonialismo. Perpetuando assim, a condição subalterna da sociedade do país colonizado. 
Nada que certos proprietários de hoje não perguntem, ameaçados pelas Propostas de Emenda Constitucional que vêm dar alforria a empregados domésticos, daqueles que 125 anos depois da escravatura ainda dormem no cubículo sem janela do condomínio, casa-grande ecofriendly, lixo reciclado, placa solar (CoElHo, 2016, p. 56).

Devido a esta colonialidade, as elites estatais e intelectuais do Brasil decidiram construir o seu Estado à semelhança do Ocidente, negando-lhe o direito a uma identidade própria e à afirmação das minorias, conduzindo-o para uma crise política interminável, como bem esclarece Tristão:

A ironia, Inês, é que cem anos atrás, quando o prefeito Pereira Passos arrasa os cortiços para fazer do Rio uma Paris, empurra essa gente pro morro. As primeiras favelas nascem desses desalojados, e dos soldados que tinham voltado da Guerra do Paraguai. E algumas gerações depois o morro está sendo empurrado pra fora pelo prefeito Eduardo Paes, que quer mais do que Paris, quer o centro do mundo (Coelho, 2016, p. 65).

Segundo Krishna (1999), designa-se este fenómeno de "ansiedade pós-colonial" e caracteriza-se pela intenção por parte das elites estatais e intelectuais e pelas classes média e alta dos países periféricos de construírem os seus Estados (passado, presente e futuro) à semelhança de outros locais que constituem o modelo, na Europa e nos Estados Unidos, até porque "nada melhor, para dar lustre às pessoas e à sociedade que formam, do que as ideias mais ilustres do tempo, no caso as europeias" (SchWARZ, 1992, p.7).

A colonialidade do poder e do saber persistiram, fazendo perdurar a condição subalterna das sociedades dos países colonizados, como Anibal Quijano (2000) tão bem demonstra nas suas investigações. Os negros e os indígenas são os $\mathrm{Ou}$ tros do branco Ocidental e a América, a África e o Oriente são os "outros" da Europa e estes "outros" sociais e geográficos ocupam os lugares inferiores na hierarquia estabelecida pelo Ocidente. Para Lugarinho (2013), o processo de dominação baseava-se no conceito de que a população colonizada não era dotada de humanidade e nem de uma "autêntica" masculinidade, por isso era feminizada e infantil. Isso justificava a sua subalternidade.

A descolonização ainda não ocorreu, na realidade, porque se perpetuou esta dominação e porque os direitos dos negros e dos indígenas continuaram a ser negados. Isso é algo que se apura ao longo de toda a obra:

- Incrível pensar nisso. Mas o que me surpreende é ver tão poucos negros entre os brancos. Ainda agora, atravessando Botafogo, ou ontem na Urca, ou na praia, os ricos parecem ser todos brancos e não se misturam.

- Há muita mistura de sangues, mas quem é negro mesmo tende a ser pobre, ou artista ou desportista (COELHO, 2016, p. 161). 
Muito embora, o sistema político de "Império Português" tenha ficado, felizmente, no passado, as suas sequelas encontram-se presentes nas novas formas de imperialismo político e económico. Atualmente é difícil acreditar que haja uma única pessoa que não saiba o que aconteceu nas colónias, conquanto haja algumas que preferem acreditar que os outros colonizadores, dos outros países realmente cometeram as maiores desumanidades, mas os portugueses nunca seriam capazes de cometer tais atos. É até por isso que, desde os "manuais escolares ao discurso público, a tónica portuguesa, hoje, é celebrar os Descobrimentos" (Coelho, 2016, p. 466).

De facto, já em 1963, Charles R. Boxer tinha desmistificado a ideia surreal que surge constantemente nas discussões sobre o colonialismo português, de que muitos portugueses acreditavam convictamente que o seu país não tolerava discriminações raciais nas colónias e que existia um ameno convívio entre todos os habitantes. Se este discurso ainda hoje persiste, são resquícios de um regime ditatorial imperialista, nacionalista com ideais de autarcia que via as colónias como as "joias da coroa". É um facto que foram escravizados e mortos milhares de negros e que foram massacrados, saqueados e humilhados outros tantos indígenas.

A propósito disto, já Sartre (1968) nas suas considerações sobre colonialismo e neocolonialismo se refere aos povos oprimidos, obrigados a vestirem-se como europeus e marcados a ferro como gado. Quanto aos negros, eram tratados como animais selvagens: enjaulados, amordaçados, silenciados, mutilados, torturados e isto é a maior evidência da tradição racista imperialista e especista europeia de conquistas, guerras e colonizações. Para este autor, o colonizador que escraviza e desumaniza outro ser humano desta forma, é um ser ambicioso que apenas pretende explorar e espoliar as riquezas tropicais naturais das colónias que seriam transformadas em manufacturas nas metrópoles europeias. E se ainda há alguns que de alguma forma pensam que nem tudo foi mau, e que todos beneficiamos da colonização porque aprendemos matérias novas até então desconhecidas e alargamos horizontes, desenganem-se porque na realidade, a ampliação do mundo devido às descobertas dos caminhos marítimos apenas alargou o horizonte geográfico e nunca novo horizontes históricos ou culturais, como bem refere Francisco Iglésias:

Tais descobertas não importavam em incorporação de outros povos: tomava-se conhecimento de que o mundo era mais amplo, explorava-se economicamente, na medida do possível, o que se revelara. E era só. Esses continentes e ilhas pouco mais sugeriam. Seus habitantes, enquanto homens, só contavam para alguns poucos abnegados religiosos. No mais, eram povos exóticos, com a atenção que sempre merecem os exotismos (IGLÉSIAS, 1971, p. 23).

Na verdade, para os "desenvolvidos" e "sofisticados" colonizadores, os nativos africanos e indígenas não passavam daquilo que eles tinham sido no passado, animais em estado de evolução, que teriam que ser educados, formados, civilizados 
e aculturados. Instaurou-se, desta forma, o domínio e a exploração sobre esta população, usando a força, que sempre é o melhor meio para demonstrar e impor a grande superioridade cultural do Ocidente em termos económicos, científicos e culturais. Superioridade que é conferida pela cultura eurocêntrica, a qual se apresenta como universal no sentido que propõe ou impõe, de alguma forma, a todos os povos a imitação do modelo como única solução aos desafios do nosso tempo (AMIN, 1989).

Esta cultura parte do princípio que a modernidade que caracteriza o Ocidente é, sem dúvida, a única que realmente importa e, como tal, todas as outras formas de modernidade desenvolvidas são, com toda a certeza, ou o resultado da disseminação do centro (Ocidente) para as periferias ou não possuem interesse nenhum. Para Blaut (1993) esta cultura que caracteriza como um "conjunto de crenças" desenvolveu-se no século XIX no colonialismo europeu e ganhou força com a hegemonia dos Estados Unidos da América durante o século XX. Nestas crenças não entram ideias de que o Ocidente poderia alguma vez ter ido buscar, ou aprender alguma coisa com as sociedades africanas, indígenas, islâmicas, chinesas e outras. Aliás, é de todo, inacreditável que necessitasse de o fazer, uma vez que o Ocidente seria mais desenvolvido que todas as outras sociedades e possuiria características intrínsecas que lhe permitiram o grande desenvolvimento do período da modernidade.

Os europeus são vistos como os "executantes da História”. A Europa está eternamente a avançar, a progredir e a modernizar-se. Quanto ao resto do mundo, avança por arrastamento ou estagna: é a "sociedade tradicional”. Assim, o mundo tem um centro geográfico permanente e uma permanente periferia: um Dentro e um Fora. O Dentro comanda, o Fora segue à distância. O Dentro busca a inovação, o Fora a imitação. Esta crença é o difusionismo, ou, mais precisamente, o difusionismo eurocêntrico. É uma teoria sobre a forma como os processos culturais tendem a movimentarse ao longo do planeta como um todo. [...] A Europa é a fonte da maioria das difusões; a não-Europa é o receptor (BlAUT, 1993, p.11).

Apesar de tudo isto, o projeto colonizador e espoliador necessitava de uma mascarilha que o fizesse parecer ilustre e benemérito e passaram a vender a ideia de que os seus objectivos primordiais eram civilizar, evangelizar, educar, levar a paz e cuidar dos indígenas e negros que até se terem cruzado com os bons samaritanos portugueses, salvadores das suas tribos e nações eram animais que praticavam costumes bárbaros de escravidão, canibalismo e sacrifícios humanos. Como bem se sabe, "o senhor-de-engenho fazia de colonizador mau: queria escravizar os índios como negros. O missionário fazia de colonizador "bom": salvaria os índios do cativeiro, e os negros seriam o custo inevitável. Uns na cruzada do lucro, outros na das almas, todos parte da Coroa Portuguesa, serviram o mais vasto tráfico atlântico conduzido por um só país, e minúsculo" (CoelHo, 2016, p. 91). Em 
boa verdade, os colonialismos impulsionados pela ideia de superioridade dos povos ocidentais tinham como único alvo a assimilação, ou seja, neste caso, "aportuguesar" os colonos. Os portugueses, como local de memória, têm o Monumento dos Descobrimentos e agem como se não houvesse mais nada que merecesse ser recordado. Como bem apresenta a autora:

como é possível que não haja um museu ou um memorial da escravatura em Portugal, quando nenhum país europeu foi responsável por escravizar tantos africanos? Ou dos povos indígenas, quando demos cabo de tantos? - Sim, nunca vejo isso nos discursos políticos.

- Se não nos virmos nesse espelho nunca seremos capazes de mudar, ir além. Acho cada vez mais que o grande problema português é a incapacidade de transformação. Fomos para o mundo a querer mudar os outros, e incapazes de ser mudados por eles. Ajeitamo-nos, mas não mudamos. Enfim, longa conversa (CoElHo, 2016, p. 163).

É urgente explorar as construções e reconstruções de significados dos vários pontos de vista sobre a história da (des)colonização portuguesa e suas consequências. A herança colonial portuguesa encontra-se presente na violência que os brasileiros vivem, particularmente no Rio de Janeiro. A realidade é que a violência é um componente da cultura brasileira, uma vez que é um dos princípios fundacionais que "organiza a própria ordem social e, como consequência, a experiência criativa e a expressão simbólica, aliás, como acontece com a maior parte das culturas de extração colonial" (Pellegrini, 2008, p. 42). Pellegrini diz que a violência é uma parte integrante da cultura brasileira porque ela está presente no país desde a sua conquista, ocupação, colonização, extermínio de índios, escravatura, e todos os outros acontecimentos que se seguiram até agora e deixaram marcas na sociedade. Como consequência, segundo esta autora, existe uma lógica específica nesta violência, uma vez que para qualquer ato violento, corresponde um motivo explicativo no universo retratado, "ou seja, existe uma explicação e uma justificativa, inerentes àquele universo ou à vida fora dele” (Pellegrini, 2008, p. 51).

\section{Notas finais}

Este livro transporta os portugueses para a questão da relação com o seu passado, no momento no qual "o filho do que foi morto falará e o filho do que matou não conseguirá entendê-lo, porque o lugar do outro está por experimentar, nunca houve transformação. Quem teme deixar de ser quem é não vai saber quem foi nem quem vai ser" (Coelho, 2016, p.466). O narrador ao conduzir os/as leitores/as pelos 500 anos que uniram a história do Brasil e Portugal durante os períodos de colonização e pós-colonização demonstra, ao longo das 551 páginas que a sociedade brasileira organizada em função do período da colonização portuguesa perpetuou, até hoje, a condição subalterna das minorias oprimidas.

Uma cultura colonizadora de conquista exclui, principalmente, negros, "mestiços" e indígenas e coloca-os, implacavelmente, em risco de violências sucessivas 
no seu quotidiano, como bem descreve Mbembe (2018). Segundo ele, a única diferença entre a era colonial e a pós-colonial, nas sociedades, reside no fato de que, na época das colonizações, a violência era um meio para atingir o lucro e atualmente acontece de forma gratuita, como um fim em si mesmo.

O Rio de Janeiro é o local da ação: uma mistura de ficção com realidade, que possui uma sociedade ao deus-dará, à qual foi negada a verdadeira identidade. Ambicionando uma que se formasse à imagem e semelhança do Ocidente, o grande modelo de superioridade intelectual. Isso contribui, de certo modo, para que os portugueses continuem a acreditar que Portugal foi um "bom" colonizador, onde nunca houve racismo ou outra forma de discriminação e, no fundo, o que se conclui com esta leitura é que não existem, de todo, "bons" colonizadores e que chegou a altura de assumir a responsabilidade pelos crimes hediondos que se cometeram nas colónias, incluindo o Brasil, como se confirma quase no final: "o passado que falta comer é futuro. Transatlântico, transmarino, ultramarino: até ficar só o azul" (COELHo, 2016, p.550).

Para além disso, a leitura desta obra confronta-nos, também, com identidades queer pós-coloniais, ou seja, com identidades subalternas que reconhecemos na diferença, porque Alexandra Lucas Coelho lhes deu visibilidade e capacidade de falar ao poder (SAID, 2008).

Muito antes de chegar à última página, aquela em que as personagens decidem cantar a música do Chico Buarque: "Diz que deu, diz que dá" (Coelho, 2016, p. 551), percebemos que este não era um livro para "inocentes". Quando dizemos "inocentes", referimo-nos não só aos do Leblon, mas a todos os que se cruzam no Rio, tão bem descritos por Carlos Drummond de Andrade. Aos ignorantes e alienados que ocupam vários recantos do Brasil e Portugal.

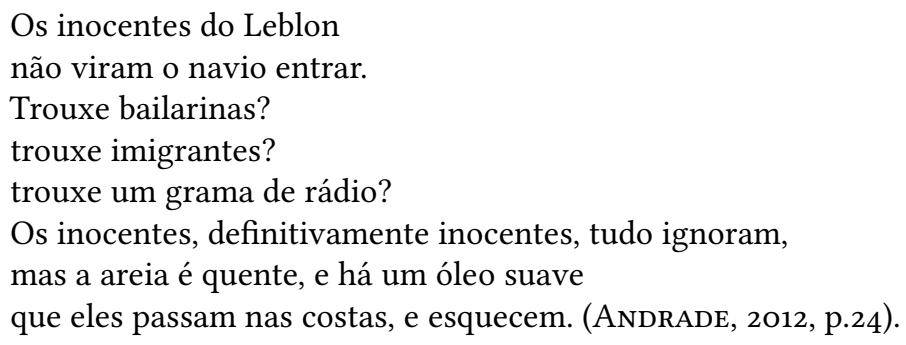

\section{Referências}

Adichie, Chimamanda. O perigo de uma história única, por Chimamanda Adichie. Por dentro de África, 2013. Disponível em http://www.pordentrodaafrica. com/cultura/o-perigo-de-uma-historia-unica-por-chimamanda-adichie. Acesso em: 27 Outubro 2019.

Amin, Samir. El Eurocentrismo: crítica de una ideología. Tradução de Rosa Cusminsky de Cendrero. México: Siglo XXI Editores, S.A., 1989. 
Andrade, Carlos Drummond de. Sentimento do Mundo. São Paulo: Companhia das Letras, 2012.

AnZAldúA, Gloria. Borderlands/La Frontera: The New Mestiza. United States: Aunt Lute Books, 1987.

Barthes, Roland. Crítica e verdade. Tradução de Leyla Perrone-Moisés. São Paulo: Perspectiva, 1999.

Blaut, James Morris. The Colonizer's Model of the World: Geographical Diffusionism and Eurocentric History. New York: Guilford Press, 1993.

Bojıć, Majda. Crítica da dimensão política da representação no romance pósmoderno e sua cumplicidade: considerações sobre Foe, de Coetzee. In XI Congresso Internacional Da Abralic: Tessituras, Interações, ConvergênCIAS. São Paulo: USP, 2008. Disponível em http://www.abralic.org.br/eventos/ cong2008/AnaisOnline/simposios/pdf/o56/MAJDA_BOJIC.pdf. Acesso em: 1 outubro 2019 .

Bourcier, Sam. Seminário Queer destaca necessidade de unificar pautas dos "abjetos" e superar institucionalização". Agência Patrícia Galvão, 2015. Disponível em http://agenciapatriciagalvao.org.br/mulheres-de-olho-2/ seminario-queer-aponta-necessidade-de-unificar-pautas-dos-abjetos-e-superarinstitucionalizacao/. Acesso em: 27 Setembro 2019.

Boxer, Charles R.. "Race Relations in the Portuguese Colonial Empire (1415-1825). London: Oxford University Press, 1963.

ButLER, Judith. Judith Butler, o 'queer' para unir as minorias através da diferença. El País, 2017. Disponível em https://brasil.elpais.com/brasil/2015/11/20/cultura/ 1447995720_144799.html. Acesso em: 28 setembro 2019.

Coelno, Alexandra Lucas.. deus-dará, Sete dias na vida de São Sebastião do Rio de faneiro, ou o Apocalipse segundo Lucas, Fudite, Zaca, Tristão, Inês, Gabriel \& Noé. Lisboa: Tinta da China, 2016.

Coelho, Alexandra Lucas. Alexandra Lucas Coelho em dois actos: Apocalipse é transformação. Shifter, 2016. Disponível em https://shifter.pt/2016/11/alexandralucas-coelho-dois-actos-apocalipse-transformacao/. Acesso em: 3 Outubro 2019.

Coelro, Alexandra Lucas (s/d). Entrevista a Alexandra Lucas Coelho. wookacontece. Disponível em https:/www.wook.pt/wookacontece/novidades/noticia/ver/ entrevista-a-alexandra-lucas-coelho/?id=125462\&langid=1. Acesso em: 1 Outubro 2019 .

Hutcheon, Linda. Poética do pós-modernismo: história, teoria, ficção. Tradução de Ricardo Cruz. Rio de Janeiro: Imago Editora, 1991.

IglésIAs, Francisco. História e Ideologia. São Paulo: Editora Perspectiva, 1971. 
Kilomba, Grada. Plantation Memories: Episodes of Everyday Racism. Münster: UNRAST-Verlag, 2010.

Krishna, Sankaran. Postcolonial Insecurities: India, Sri Lanka, and the Question of Nationhood. Minneapolis: University of Minnesota Press, 1999.

Lugarinho, Mário César (2013). Masculinidade E Colonialismo: em direção ao "homem novo" (subsídios para os estudos de gênero e para os estudos póscoloniais no contexto de língua portuguesa). Revista do Núcleo de Estudos de Literatura Portuguesa e Africana da UFF, Vol. 5, nº 10, pp. 15-38, 2013. Disponível em https://www.researchgate.net/publication/280576581_MASCULINIDADE_ E_COLONIALISMO_EM_DIRECAO_AO_HOMEM_NOVO_SUBSIDIOS_PARA_ OS_ESTUDOS_DE_GENERO_E_PARA_OS_ESTUDOS_POS-COLONIAIS_NO_ CONTEXTO_DE_LINGUA_PORTUGUESA. Acesso em: 3 outubro 2019.

Magritte, René. A Traição das Imagens. Museu de Arte do Condado de Los Angeles, 1929.

Mbembe, Achille. Necropolítica. São Paulo: n-1 edições, 2018.

MckeOn, Michael. Introduction. In: Theory of the novel: a historical approach. Baltimore/Londres: The Johns Hopkins University Press, 2000.

Obinwanne, Ashley; BLAIR, Bit (2017). Why I'm a Lesbian (Not Queer). Lesbians Over Everything. Disponível em http://lesbiansovereverything.com/why-ima-lesbian-not-queer/. Acesso em: 4 outubro 2019.

Pavlenko, Aneta. The Bilingual Mind And What it Tells Us about Language and Thought. Philadelphia: Temple University, 2014.

Pellegrini, Tânia. "No fio da navalha: literatura e violência no Brasil de hoje". In: Dalcastagnè, Regina (org.). Ver e imaginar o outro: alteridade, desigualdade, violência na literatura brasileira contemporânea. São Paulo: Horizonte, pp. 41-56, 2008.

Pesavento, Sandra Jatahy. Cidades Visíveis, Cidades Sensíveis, Cidades Imaginárias. Revista Brasileira de História, vol. 27, n 53, pp. 11-23, 2007.

Preciado, Beatriz. Multidões Queer - Notas para uma política dos "anormais. Estudos Feministas, Florianópolis, 19(1): 312, pp.11-20, 2011. Disponível em http: //www.scielo.br/scielo.php?script=sci_arttext\&pid=So104-026X2011000100002. Acesso em: 3 Outubro 2019.

Quijano, Aníbal. La colonialidad del poder: eurocentrismo y América Latina. In Edgardo Lander (ed.). La colonialidad del saber: eurocentrismo y ciencias sociales. Perspectivas latinoamericanas, Buenos Aires: Clacso, 2000.

SAID, Edward. Orientalismo, Barcelona: Debolsillo, 2008.

SARTre, Jean Paul. Reflexões sobre o racismo. São Paulo: Difusão Européia do Livro, 1968. 
Sedgwick, Eve Kosofsky. Epistemología del Armario. Barcelona: Ediciones de la Tempestad, 1998.

Schwarz, Roberto. Ao Vencedor As Batatas. São Paulo: Duas Cidades, 1992.

Torres, Diana. Coño Potens, Manual sobre su poder, su próstata y sus fluidos. Navarra: Editorial Txalaparta, S.I.I, 2015.

Waugh, Patricia. Metafiction, The Theory and Practice of Self-Conscious Fiction. London and New York: Routledge, 1984.

Recebido em 28 de novembro de 2019.

Aprovado em 2 de março de 2020.

\section{Resumo}

deus-dará: o Rio de Janeiro como espaço de (des)encontro durante séculos

\section{Helena Gonçalo Ferreira}

deus-dará é um romance de Alexandra Lucas Coelho, descrito ao longo de sete dias, em diferentes anos, revelando uma clara inspiração no Génesis, que nos apresenta sete personagens como o seu subtítulo destaca: "sete dias na vida de São Sebastião do Rio de Janeiro ou o Apocalipse segundo Lucas, Judite, Zaca, Tristão, Inês, Gabriel \& Noé”. Através destas personagens e com o Rio de Janeiro presente, o narrador híbrido que tanto escreve em português de Portugal como em português do Brasil, conduz os leitores ao longo de cinco séculos de história, às conjunturas sociais, religiosas e culturais de Portugal e do Brasil durante o período de colonização e pós-colonização. Partindo, então, dos trabalhos académicos que refletem sobre os estudos pós-coloniais, pretende-se, através desta obra, explorar as construções e reconstruções de significados dos vários pontos de vista sobre a história da (des)colonização portuguesa e suas consequências, uma vez que para além da herança colonial portuguesa que se vê na violência que os brasileiros vivem, particularmente, no Rio de Janeiro, este livro transporta os portugueses para a questão da relação com o seu passado, no momento presente.

Palavras-chave: deus-dará, Alexandra Lucas Coelho, Rio de Janeiro, colonização, colonialidade. 